inhibitor by the bulk medium ${ }^{6}$.

The latest results are actually a spin-off from work on mesoderm induction, which in Xenopus occurs before neural induction, while the embryo is still at the blastula stage. It has been known for a few years that activin is a highly potent mesoderm inducer ${ }^{7,8}$, and Melton's laboratory designed a dominant-negative activin receptor $(\triangle 1 \mathrm{XAR} 1)$ which could ablate the activity of the endogenous receptor when overexpressed in embryos ${ }^{9}$. This did produce embryos with reduced mesoderm, although it is now known that the reagent is not specific for activin and also inhibits the action of other members of the transforming growth factor (TGF $\beta$ ) family such as Vg-1 (D. Melton, S. Schulte-Merker and L. Dale, personal communications). Very surprisingly, when $\triangle 1 X A R 1$ was overexpressed in isolated explants of ectoderm it produced substantial neural inductions ${ }^{9}$.

This effect is now described at greater length in a follow-up paper ${ }^{1}$. The neural inductions are anterior in character and arise directly, without the intervening formation of dorsal mesoderm. The authors suggest that these results mean that neural induction is caused by the removal of ubiquitous and tonic levels of TGF $\beta$ like factors. The second paper ${ }^{2}$ associates the effect more closely with activin itself by the use of follistatin, a protein which has a higher specificity in that it inhibits activin but not $\mathrm{Vg}-1$. The follistatin gene was cloned from Xenopus and shown to be expressed in the prospective neural-inducing region of the embryo. When it is overexpressed in ectoderm it produces neural inductions, which like the $\triangle 1 X A R 1$-induced inductions are of anterior character and formed without mesoderm.

The authors would obviously like follistatin to be the endogenous neural inducer and for it to operate by removing a low tonic level of activin from its domain of expression. But the case is not yet closed. To prove that a particular substance does a particular job in vivo, three criteria must be satisfied: first, the substance must have the appropriate biological activity; second, it must be expressed at the right time and place in the embryo; and third, if it is taken away then the process should fail. Follistatin satisfies the first two criteria (it works and it is there). But we do not yet have an experiment on Xenopus in which follistatin itself is inhibited, which might be predicted to lead to a failure of neural plate formation. The follistatin gene has been mutated to inactivity in the mouse by targeted mutagenesis, and although these mice die soon after birth, the formation of the early nervous system appears to be normal (M. M. Matsuk and A. Bradley, personal communication). This suggests that in the mouse embryo follistatin either plays no role in neural induction, or is at least dispensable.

Although the idea of the 'inducing factor that never was' is appealing, positive neural-inducing factors are probably also at work. In the last year, two substances have finally been discovered which have neuralizing activity in Xenopus. One is the secreted protein encoded by the noggin gene, which has both dorsalizing activity on ventral mesoderm and neuralizing activity on ectoderm ${ }^{10,11}$. These two properties correspond closely to our understanding of the functions of the organizer region in Xenopus ${ }^{12}$, where noggin is indeed normally expressed ${ }^{13}$. The other substance is fibroblast growth factor, normally thought of as a mesoderm-inducing factor, but also able to neuralize gastrula ectoderm cells so long as they are dissociated $^{14}$.

Interestingly, the new work is consistent with an older theory of neural patterning, advanced in 1952 by P. Nieuwkoop, called the 'activation-transformation theory ${ }^{15}$. This postulated an 'activation' step at which the whole neural plate was initially induced with an anterior specification, and a 'transformation' step at which more posterior levels were induced from its neural plate by another signal from the posterior part of the mesoderm. Both noggin and follistatin induce anterior-type neural markers and not posterior ones, suggesting that they correspond to 'activation' factors. This is why Cordelia would have got the brain, while the silky-tongued Regan and Goneril would have received more posterior territories. The likelihood is that a complex process such as neural induction will turn out to involve quite a variety of factors, both positive and negative, and that we have so far found the first few of them.

J. M.W. Slack is in the ICRF Developmental Biology Unit, Department of Zoology, University of Oxford, South Parks Road, Oxford OX1 3PS, UK.

1. Hemmati-Brivanlou, A. \& Melton, D. A. Cell 77, 273-281 (1994).

2. Hemmati-Brivanlou, A., Kelly, O.\&Melton, D. A. Cell77, 283-295 (1994).

3. Needham, J. Biochemistry and Morphogenesis (Cambridge Univ. Press, 1942)

4. Otte. A. P., Koster, C. H., Snoek, G. T. \& Durston, A. J. Nature 334, 618-620(1988)

5. Godsave, S. F. \& Slack, J. M. W. Devl Biol. 134, $486-490$ (1989).

6. Godsave, S. F. \& Slack, J. M. W. Development 111 523-530 (1991)

Smith, J. C. Price, B. M. J. Van Nimmen, K. \& Huylebroek. D. Nature 345. 729-731 (1990)

8. Asashima, M. et al. Wilhelm Roux Arch. dev. Biol. 198. 330-335 (1990).

9. Hemmati-Brivanlou, A. \& Meiton, D. A. Nature 359. 609-614 (1992).

10. Smith. W. C., Knecht, A. K., WU, M. \& Harland, R. M. Nature 361. 547-549 (1.993)

11. Lamb, T.M. etal. Science 262, 713-718 (1993)

12. Smith, J. C. \& Slack, J. M. W. J. Embryol. exp. Morph. 78 299-317 (1983).

13. Smith, W. C. \& Hariand, R. M. Cell 70, $829-840$ (1992).

14. Kengaku, M. \& Okamoto, H. Development 119 1067-1078 (1993)

15. Nieuwkoop. P. D.J. exp. Zool. 120, 83-108(1952).

\section{Read my tyres}

THE car is taking over the world. Modern economies judge their health by their motor industries; new roads are jammed as soon as they open; every city is choked with road traffic. One solution is road pricing. At the moment this requires every car to carry an expensive electronic transponder.

Daedalus has a neater idea. He points out that a car stamps a signature, its tyre pattern, on every inch of road it traverses. He plans to read this signature.

One way would be to mould an individual black and white bar code into every tyre. It could be scanned by a reader set into the road at each pricing point. The system would come into being quite automatically, as people replaced their worn tyres with the new coded ones. But individually coded tyres would be expensive. It would be cheaper to put a magnetic filler in the tyre rubber. The tread pattern could then be read magnetically by sensors in the road. Four detailed tyre patterns, each changing slowly with wear, should be an easily recognizable fingerprint.

Even better, a magnetic tyre could be given a special magnetic code, like the one on a credit card stripe. When the car was licensed, its tyres would be coded; thereafter, magnetic readers in the road could recognize it.

There would be problems, of course. The motor trade, legendary for its sharp operators, would not welcome its role as government informer and enforcer. Unscrupulous dealers would erase the coded tyres with a magnet, or record false codes on them. To counter such trickery, Daedalus's magnetic road. readers will also write on the tyres as they pass. They will mark each tyre with a code that can be checked and updated by successive readers all down the road. Every car would then leave such a detailed trail that attempted frauds and evasions could be swiftly detected.

Daedalus goes even further. A car with magnetically coded tyres could act as a smart credit card. Its driver could pay for petrol, parking, drive-in fast food, even road pricing itself, 'on the hoof', so to speak. Those simple souls to whom cars and credit cards are both mainly forms of ostentation might be happy to combine the two. Their cars would then define their identities literally as well as spiritually. The bureaucrats of the encroaching computerized state would be well pleased. Their road readers would tell them the exact location and bank balance of every significant citizen all the time. Insignificant citizens, that is, those without cars, would be even more of an underclass than they are now.

David Jones 